\title{
RECIPES AND HOUSEHOLD HINTS
}

With Fall weather setting in and the Thanksgiving and Christmas holidays fast approaching, Americans return to the indoor life of warm meals around the family table and evenings spent by the fire place in the warmth and security of our homes. A woman's thoughts turn to baking bread and making soup.

Here are a few recipes and household hints from the Falcon Cook Book, published by Shannon and Mott. The date of publication is unknown but Falcon Flour was the product of the Des Moines Roller Mills which operated between 1893 and 1917.

\section{JohnNie Cake}

Three tablespoons Falcon flour, three tablespoons sugar, one-half cup shortening, two eggs, salt, one pint sour milk, one teaspoon soda, corn meal to make good batter, not too stiff. Bake in shallow pan.

Mrs. G. W. Blasdell.

\section{Oyster Shortcake}

Crust: Two cups Falcon flour, two teaspoons baking-powder, one-half teaspoon salt, two teaspoons butter, three-fourths cup milk. Mix very soft and bake in two layers buttering between. When baked split open and pour over it as follows: One-half pint oysters, one and one-half cups milk and three tablespoons butter, three tablespoons Falcon flour. Scald the oysters. Make a white sauce of butter, flour and milk and liquor from the oysters. Add to the scalded oysters, salt and pepper.

Mrs. J. X. Christina

\section{Vegetable Soup}

Wash soup meat, cover with cold water and let it simmer. Add one teaspoon of salt to every quart of water, six potatoes cut in small cubes, one-third can tomatoes and two tablespoons of rice. Other vegetables chopped fine may be added if desired. 


\section{To Save Dentist Bills}

1. After each meal always clean the teeth, use dental floss and fill mouth with water and as you eject it make it flush through the teeth. You will be surprised perhaps to get a berry seed left from two or three days before. Never go to bed without cleaning the teeth.

2. Should there be a little rough place at the top of a tooth, a forerunner of decay, with a hard, flat toothpick scour occasionally under the gum with pumice and glycothymolene. This will put off the dreaded filling a long time.

3. Should the teeth ache in the night it is probably due to the condition of the stomach and by getting up and cleaning the teeth the ache will stop.

4. Often to rinse the mouth in first warm, then cold water will stop tooth-ache.

5. After a severe filling of tooth go home and rest.

Matilda Buchanan

\section{Miscellaneous}

Place small thimble on end of rod to put it through casing of lace curtains after laundering.

For cleaning the bath tub and wash stand use gasoline on a soft cloth.

Nothing better than lemon for removing fruit stains from the hands.

If a piece of blotting paper is placed under the soiled place in a garment while cleaning with gasoline there will be no dark ring around the place cleaned.

Lemon juice and salt will remove rust and ink.

Molasses will remove grass stain by putting it on soiled spots and let it remain on the spot for twenty-four hours.

Make a paste of starch and skimmed milk to remove ink spots.

One tablespoonful of household ammonia to one gallon of water used about once a month in watering ferns will make them grow beautifully. 
Copyright of Annals of Iowa is the property of State of Iowa, by \& through the State Historical Society of Iowa and its content may not be copied or emailed to multiple sites or posted to a listserv without the copyright holder's express written permission. However, users may print, download, or email articles for individual use. 